\title{
A methodological approach to estimate soil corrosivity for archaeological copper alloy artefacts
}

\author{
Omid Oudbashi* (10)
}

\begin{abstract}
Characterization of soil corrosivity in archaeological sites is an important subject to understand the conservation conditions of archaeological bronze collections and helps conservators to prepare a conservation strategy for long term preservation of bronze objects. In this paper, a research approach is established to identify soil corrosivity in two archaeological sites and to find correlation between corrosion events and soil characterizations. Therefore, an analytical study was carried out to identify different factors of soil environment influencing corrosivity of the soil in two sites. Based on the results, measuring different factors such as chemical composition, $\mathrm{pH}$, texture, soluble salts and water content and SOM displayed different soil environments in two archaeological sites. The results represent correlative relationship between corrosion mechanism and soil characteristics in these archaeological sites.
\end{abstract}

Keywords: Archaeological conservation, Archaeological copper alloys, Soil corrosivity, Soluble salts, Soil moisture

\section{Introduction}

Soil is a complex environment with various parameters, that influences archaeological materials in long term burial and causes to change appearance and the chemical nature of the buried objects. Archaeological metals suffer different corrosion events during burial time that may lead to formation of different corrosion layers on their surface with variable thicknesses and chemical compositions. These corrosion layers may form in different forms from a thin multiple corrosion layer to a thick corrosion crust covering remnants of original metal, and in some cases a completely corroded object without any metallic remnant may be discovered [1,2]. Different parameters affect the corrosion events in archaeological metals that may be related to the metallurgy of the artefact (e.g. composition and manufacture), or the characteristics of the burial soil (e.g. texture, $\mathrm{pH}$, redox potential, soluble salts) [3-11].

Corrosion of archaeological bronzes in soil environment has been subjected for many researches in last

\footnotetext{
*Correspondence: o.oudbashi@aui.ac.ir

Department of Conservation of Historic and Cultural Properties, Faculty of Conservation, Art University of Isfahan, Isfahan, Iran
}

decades. These multidisciplinary studies could be categorized into three main groups:

- Studies about corrosion morphology in buried bronzes [12-14],

- Studies to identify corrosion compounds and products, phenomena and mechanisms in bronze corrosion [15-18].

- Studies on the effect of burial environments and soil conditions on corrosion of archaeological bronzes [19-22].

Usually, archaeological metals are placed in the soil for a long time period and it makes difficult or even impossible to follow up the corrosion processes during burial time. In fact, the conditions of the archaeological metals are the results of interaction between metal/alloy and soil that can be observed only after unearthing the objects. On the other hand, soil environment may alter during the millennia that leads to change the soil conditions during burial time; indeed, the soil that is excavated today, may be different from the soil that objects are abandoned in it at the first time. Thus, study of the soil conditions 
in archaeological sites and comparing the results with the corrosion mechanism in the excavated materials can lead to better identification of long term corrosion mechanism in archaeological artefacts.

The aim of this research is to understand the effect of soil characteristics on the corrosivity of the burial environment as a medium that influences corrosion in the archaeological bronzes. In this paper, the soil conditions are determined regarding to the corrosivity of the soil environment and the effects of long term burial conditions on the corrosion are studied in some excavated bronze artefacts from two archaeological sites from Iran, the Sangtarashan Iron Age and the Haft Tappeh Elamite sites, by analysis different soil parameters and evaluation of soil corrosivity in the sites by using an integrated soil assessment approach based on the data obtained from soil analysis. Finally, the correlation between soil conditions and corrosion mechanism in the bronze artefacts are discussed.

\section{Materials and methods Archaeological sites}

Two archaeological sites are selected to study on soil corrosivity and soil effects on conservation condition of archaeological bronze objects. These sites are Haft Tappeh Middle Elamite site (second millennium BC) located in southwestern Iran in the Khuzestan plain and the Sangtarashan Iron Age Site (first millennium BC) located in Luristan, western Iran (Fig. 1).

The archaeological soil of Sangtarashan includes two specific parts: the surface soil in black-brown colour with about $20-30 \mathrm{~cm}$ depth, apart from the slope of the hill in the northern part of the site that it is about $100 \mathrm{~cm}$ in depth, and the red soil under the black-brown one that is the main soil of the area. This second layer is from ca. 30 to $100 \mathrm{~cm}$ in depth from the surface of the site and is the burial environment in which the archaeological remains were discovered. The bronze objects also are found in the red soil or the interface of the red and black-brown soils. Of course, a very thin layer in dark brown colour is observed over the black-brown soil that is influenced by recent agricultural activities and is very similar to the black-brown soil (Fig. 2a). Furthermore, the Haft Tappeh site has a different situation, apart from a few centimetres upside the surface that are dated to the Parthian-Sasanian period (beginning of the first millennium $\mathrm{AD}$ ), all of the burial environment (in some areas more than $200 \mathrm{~cm}$ ) is dated to the middle Elamite period. The colour of the soil is similar in the surface and in the depth of the Haft Tappeh site (Fig. 2b). The bronze objects are discovered in different depths of the Haft Tappeh soil medium.

\section{Estimation of degree of deterioration (Fdet)}

Nord et al. [20,21] suggested an estimating factor to represent corrosion severity in archaeological copper alloy objects, named as the degree of deterioration $(F d e t)$. They classified the objects in five groups regarding to the volume of corrosion occurred and observed in the cross section of copper alloy objects. In current study, based on the cross section of selected bronze samples from two sites, a new Fdet was designed including six groups of

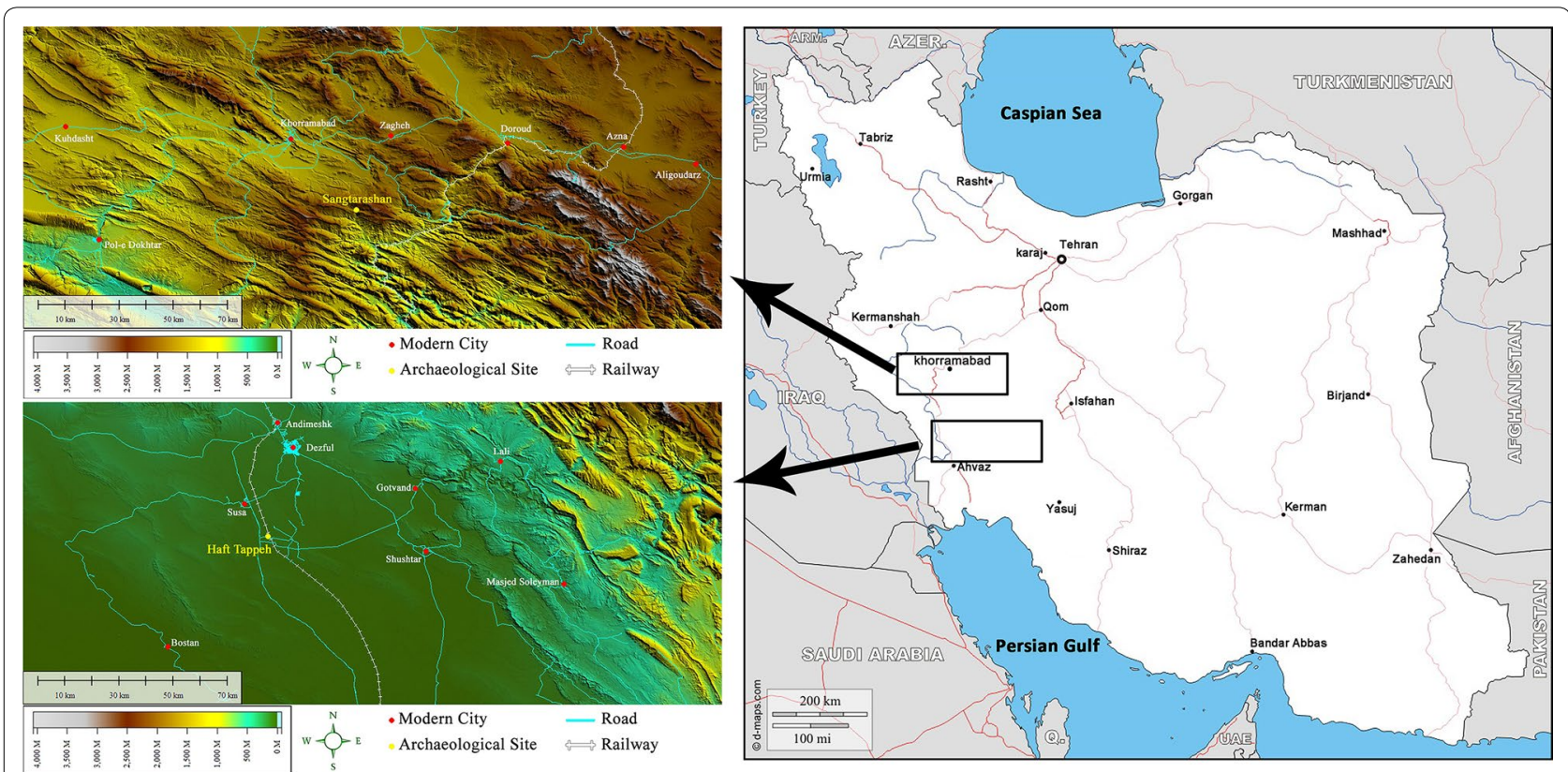

Fig. 1 Map of Iran and location of two archaeological sites studied in this paper 

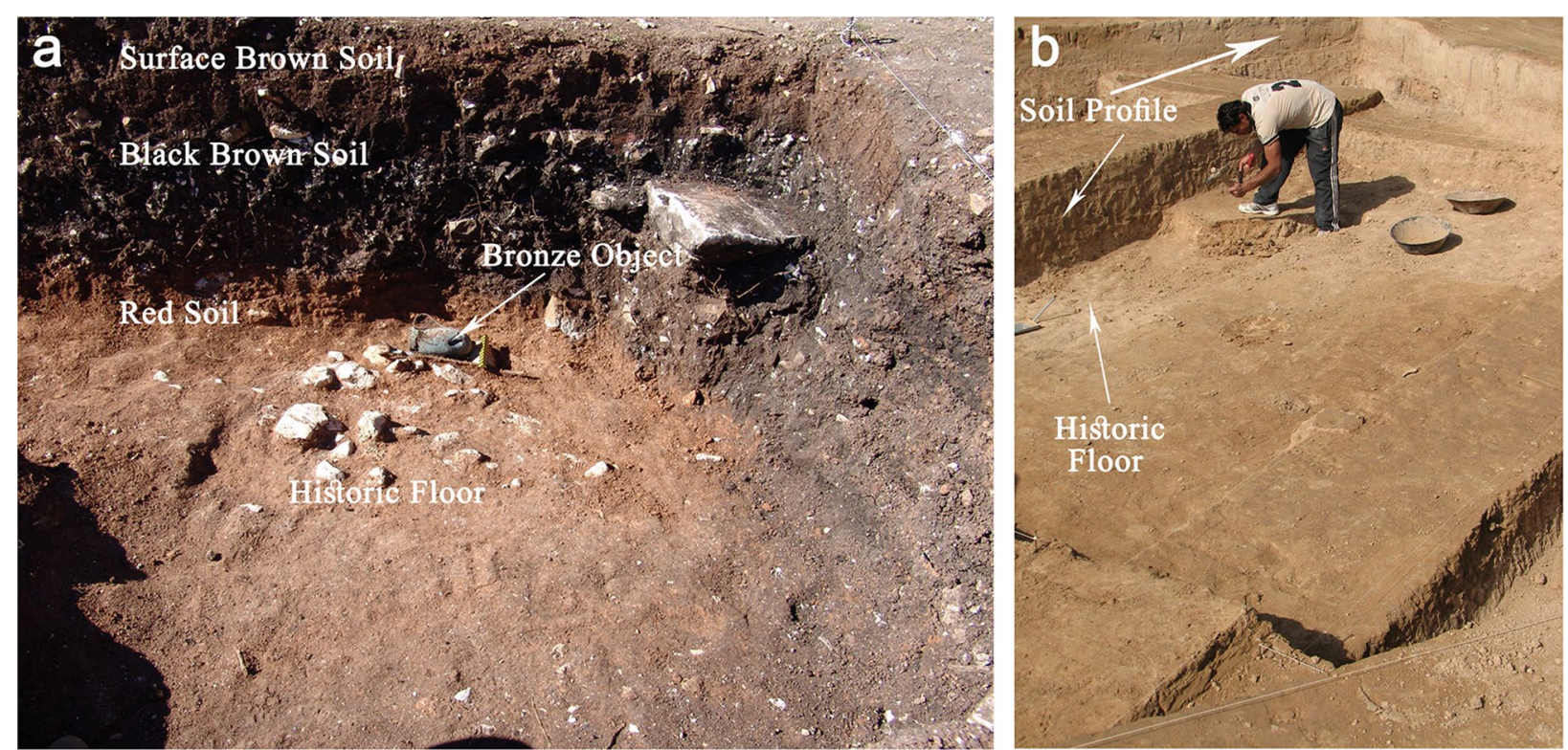

Fig. 2 a Soil profile in Sangtarashan site and place of finding a bronze object, $\mathbf{b}$ an excavation trench, architectural findings and soil profile in the Haft Tappeh archaeological site

objects based on the volume of corrosion penetration into the metallic microstructure. It helps to characterize the penetration of corrosion in bronze structure in more details and shows that how the bronze objects are affected by soil environment. Although many bronze objects are discovered from two archaeological sites, 26 bronze samples were selected from Haft Tappeh and 22 samples from Sangtarashan. As mentioned above, the corrosion penetration and Fdet were estimated by observing the mounted cross section of the samples [23].

\section{Soil sampling}

Six soil samples from each site were selected from three different areas to undertake analytical study on soil and estimate soil corrosivity of two archaeological sites. The Haft Tappeh samples were selected from three trenches during the archaeological excavations in 2012 (trenches 27, 294 and 298) [24]. Three samples were selected from the surface of the trenches $(0-30 \mathrm{~cm}$ of the surface) and three samples from the depth near the archaeological architectural floor of the Middle Elamite period. The Sangtarashan samples were selected from three trenches (trenches J16, E12 and H18) during 2009 and 2011 excavation seasons [23]. Three samples from black-brown surface soil and three samples of red deep soil were selected. The characteristics of soil samples are presented in Table 1.

Table 1 Characteristics of the soil samples from two archaeological sites of Haft Tappeh and Sangtarashan

\begin{tabular}{|c|c|c|c|c|c|}
\hline Sample & Sample type & Trench & Depth of sampling $(\mathrm{cm})$ & Munsell code & Colour \\
\hline HT.01 & Surface & 27 & 30 & $10 Y R 6 / 4$ & Dull yellow orange \\
\hline HT.02 & Deep & 27 & 90 & 10YR 6/4 & Dull yellow orange \\
\hline HТ.03 & Surface & 294 & 30 & 10YR 5/3 & Dull yellowish brown \\
\hline HT.04 & Deep & 294 & 150 & $10 Y R 7 / 3$ & Dull yellow orange \\
\hline HT.05 & Surface & 298 & 30 & 10YR 7/3 & Dull yellow orange \\
\hline HT.06 & Deep & 298 & 180 & $10 Y R 6 / 3$ & Dull yellow orange \\
\hline ST.01 & Surface & J16 & 30 & 7.5YR 2.5/2 & Brownish black \\
\hline ST.02 & Deep & $J 16$ & 80 & 5YR 4/4 & Dull reddish brown \\
\hline ST.03 & Surface & $\mathrm{E} 12$ & 30 & 7.5YR 3/1 & Brownish black \\
\hline ST.04 & Deep & E12 & 90 & $5 Y R 3 / 3$ & Reddish \\
\hline ST.05 & Surface & $\mathrm{H} 18$ & 30 & 7.5YR 4/1 & Brownish grey \\
\hline ST.06 & Deep & $\mathrm{H} 18$ & 70 & $5 Y R 4 / 2$ & Greyish brown \\
\hline
\end{tabular}




\section{Methods of soil analysis}

The analytical methods were selected and designed based on two main aspects: identification of soil type and characterization of physico-chemical factors influencing soil corrosivity. Thus, two analytical systems were performed to find different features of the soil in the archaeological sites: instrumental as well as standard and classic analytical methods.

First to remove free water from the soil texture, all samples were dried in the open air [25]. Then the samples were separated into two parts: the first part was used to analytical studies and soil particle size analysis test. The second one was sieved with sieve mesh size of No. 10 $(2 \mathrm{~mm})$ [26] and was used for other tests, including characterization of soluble ions (soluble salts), $\mathrm{pH}$ measurement, electrical conductivity test (EC), and measuring soil water and soil organic matter.

Soil samples were analysed by X-ray fluorescence (XRF) method [26-28]. For this purpose, $5 \mathrm{~g}$ of each sample were selected and prepared for XRF analysis. The samples were analysed by an ARL 8410 WDXRF analyser. The XRF analyses were carried out on the powder pellets. Also, the phase compounds in the soil samples were determined by X-ray diffraction method [26, 28-30]. Also, 4 grams of each sample were powdered and analysed by an X-ray diffractometer MPD 3000 model manufacture by GNR company.

Soil particle size distribution was measured by the sieve and hydrometer method in samples of two archaeological sites based on the standard method ASTM D422-63 [31].

Water and soil organic matter (SOM) contents of soil samples were calculated by heating the sieved samples in an oven and then burning off in a furnace (L.O.I) and were measured based on the weight loss during these processes. Five grams of each sample were heat $12 \mathrm{~h}$ in an oven in $105{ }^{\circ} \mathrm{C}$ and then water content was measured in percent based on loss of weight after heating [26, 32, 33]. There are different methods and variable temperatures to determine soil organic matter in the soil, but to void the effect of high temperature on different soil constituents, heating in $360{ }^{\circ} \mathrm{C}$ was selected [34-36]. Thus, the samples were heated and dried in oven then were heated in a furnace in $360{ }^{\circ} \mathrm{C}$ for $4 \mathrm{~h}$. The weight change after heating was considered in percent as SOM content of the soil samples [34].

The $\mathrm{pH}$ of soil samples was analysed by a $\mathrm{pH}$-meter Metrohm 744 model based on ASTM standard test [37].

The soil electrical conductivity (EC) may be an important factor showing soil salinity and consequently its corrosivity because it may present the soluble salt content in the soil [38-40]. For this purpose, the dried and sieved soil samples were selected and an extract was prepared from each sample with $1 / 2$ proportion of soil and water respectively. This extract proportion was prepared based on the water content measured in the samples [26]. Then, the EC of soil samples was determined in the extracts by a conductometer InoLab Terminal 740 manufactured by WTW Company.

The $1 / 2$ extract of soil/water was also used to determine soluble anions in the soil samples [26, 39]. A preliminary qualitative test was done on the soil samples to detect the soluble anions present in the samples, including $\mathrm{HCO}_{3}{ }^{-}, \mathrm{CO}_{3}{ }^{2-}, \mathrm{SO}_{4}{ }^{2-}, \mathrm{NO}_{3}{ }^{-}, \mathrm{PO}_{4}{ }^{3-}, \mathrm{Cl}^{-}[41]$. Based on the results of qualitative tests, soluble sulphate, carbonate, nitrate and chloride were measured in the soil samples. To identify the soluble chloride content, titration (Mohr) method was used based on ASTM standard $[26,39,42]$. Soluble carbonate and bicarbonate content also was determined by titration method with sulphuric acid and based on ASTM standard [39, 43]. Soluble sulphate content was determined by turbidity measurement using spectrophotometry method with a SPECTRONIC 20 spectrophotometer manufactured by $\mathrm{BAUSCH}$ \& LOMB company [39]. Finally, soluble nitrate was measured by ion chromatography method [44].

The soluble cations including $\mathrm{Na}^{+}, \mathrm{Mg}^{2+}, \mathrm{K}^{+}$and $\mathrm{Ca}^{2+}$ were measured by flame atomic absorption spectroscopy (FAAS) method [39] on the $1 / 2$ extract of soil/ water by using a Perkin-Elmer 2380 Atomic Absorption Spectrometer.

\section{Results}

\section{Previous results on the corrosion of the objects}

Corrosion mechanism and morphology in the bronze objects of these archaeological sites are studied previously. The result showed that the main corrosion mechanism in the Haft Tappeh bronze collection is active corrosion (bronze disease). The main corrosion products identified in the Haft Tappeh bronzes are copper oxides (cuprite, tenorite) and copper trihydroxychlorides (atacamite, paratacamite); while uniform corrosion with noble patina is observed in Sangtarashan bronze objects with cuprite, malachite and azurite as the main corrosion compounds $[45,46]$.

Nevertheless, some details should be explained here to find relationship between soil condition and corrosion in archaeological copper alloy objects. Haft Tappeh objects are made of impure copper and tin bronze alloy and are corroded heavily, as many of the objects are corroded completely and no metallic structure is retained after long term burial in the soil environment. As mentioned above, the main corrosion mechanism in these objects is bronze disease or active corrosion that is reaction of copper with chloride resulting to form basic copper chlorides and copper oxides [47]. The corrosion morphology of Haft Tappeh objects includes various red, 
green, white-grey and black corrosion layers in partially and completely corroded objects [46]. The Sangtarashan objects are corroded partially by forming a smooth noble patina on the surface of bronze objects as well as the formation of an external corrosion layer consisting of basic copper carbonates so-called as type I corrosion [12]. This corrosion morphology is occurred in Sangtarashan bronzes by internal oxidation of tin and selective dissolution of copper [45].

\section{Soil appearance}

The appearance of Haft Tappeh soil samples consist of a fine grained soil with many white particles that may be the remnants of gypsum used as the binder or plaster in the Elamite buildings of Haft Tappeh [48, 49]. Some very fine black particles are also visible in the soil samples that may be charcoal particles from burning the site at the ancient time [50]. Soil samples of Sangtarashan are including three dark samples from the surface and three red samples from the depth of the site. Some large white particles are visible in the Sangtarashan soil that may be small pieces of broken rocks that are used to build the sanctuary during the Iron Age [51]. Table 1 also presents the colour characteristics of soil samples from two archaeological sites. The colour of soil samples is specified by Munsell soil chart method [52-54].

\section{Chemical composition}

Results of XRF analysis of soil samples are presented in Table 2. Based on the results $\mathrm{SiO}_{2}, \mathrm{CaO}, \mathrm{Al}_{2} \mathrm{O}_{3}, \mathrm{Fe}_{2} \mathrm{O}_{3}$, $\mathrm{MgO}$ and $\mathrm{K}_{2} \mathrm{O}$ are the main constituents in the composition of all samples. Haft Tappeh soil samples contain $\mathrm{SO}_{3}$ as major and $\mathrm{Na}_{2} \mathrm{O}$, and $\mathrm{Cl}$ as minor constituents while metallic contaminations are detected in Sangtarashan soil as minor/trace constituents $\left(\mathrm{Co}_{3} \mathrm{O}_{4}, \mathrm{NiO}, \mathrm{MnO}\right.$, $\mathrm{CuO}, \mathrm{ZnO}$ ). It is evident that the soil samples are similar in each site, although some variations are visible in their composition such as high amounts of $\mathrm{SO}_{3}$ in sample HT.01 in Haft Tappeh or different main composition in sample ST.06 in Sangtarashan.

Results of XRD analysis are presented in Table 3. The main compounds in soils are quartz, calcite, dolomite and illite that are detected in all samples. Other commonplace phases of soil such as albite, microcline, hematite, clinochlore and nantronite are identified as soil components in some samples. Significant feature of Haft Tappeh and Sangtarashan samples in presence of different types of calcium sulphate minerals, including gypsum, basanite and anhydrite, especially in Haft Tappeh soil samples. Also sylvite $(\mathrm{KCl})$ is detected as a minor phase in one sample of Haft Tappeh.

\section{Measurement of corrosivity factors}

Different factors affecting to the corrosivity of soil environment in archaeological sites were measured to understand the correlation between the soil environment and corrosion events occurred in bronze objects of two archaeological sites. The results are presented in Table 4.

Results of particle size analysis showed that the soils of two sites are different based on three main constituents characterizing the soil types: sand, silt and clay. In Table 4 it is visible that sand amount in surface samples of Haft Tappeh is similar while in the deep samples is partially variable, but sand amount is variable in all samples of Sangtarashan (between 8 and 33\%). Nevertheless, all samples could be classified as fine grained soils because of low amount of the sand in their texture regarding to the Unified Soil Classification System (USCS) [55]. Figure 3 shows the soil classification ternary diagram of sand-silt-clay. The measured amount of these main factors in the soil of two archaeological sites are marked on the standard diagram of USDA classification [56]. Based

Table 2 Results of XRF analysis of soil samples from two archeological sites (wt\%)

\begin{tabular}{|c|c|c|c|c|c|c|c|c|c|c|c|c|c|c|c|c|c|}
\hline & $\mathrm{SiO}_{2}$ & $\mathrm{CaO}$ & $\mathrm{Al}_{2} \mathrm{O}_{3}$ & $\mathrm{Fe}_{2} \mathrm{O}_{3}$ & $\mathrm{MgO}$ & $\mathrm{K}_{2} \mathrm{O}$ & $\mathrm{SO}_{3}$ & $\mathrm{P}_{2} \mathrm{O}_{5}$ & $\mathrm{TiO}_{2}$ & $\mathrm{Cl}$ & $\mathrm{Na}_{2} \mathrm{O}$ & $\mathrm{Co}_{3} \mathrm{O}_{4}$ & $\mathrm{NiO}$ & $\mathrm{MnO}$ & $\mathrm{CuO}$ & $\mathrm{ZnO}$ & L.O.I \\
\hline HT.01 & 21.8 & 25.7 & 5.1 & 3.8 & 3.0 & 1.8 & 13.6 & 0.22 & 0.36 & 1.2 & 0.88 & - & - & - & - & - & 22.48 \\
\hline HT.02 & 31.1 & 26.5 & 6.8 & 4.2 & 3.9 & 2.1 & 2.2 & 0.11 & 0.40 & 0.14 & 0.33 & - & - & - & - & - & 22.40 \\
\hline HT.03 & 35.7 & 26.7 & 7.5 & 4.7 & 4.3 & 2.6 & 3.1 & 0.21 & 0.46 & - & 0.58 & - & - & - & - & - & 14.16 \\
\hline HT.04 & 32.0 & 21.5 & 6.4 & 3.9 & 4.0 & 2.6 & 0.74 & 0.43 & 0.38 & 0.85 & 0.74 & - & - & - & - & - & 26.60 \\
\hline HT.05 & 28.9 & 23.7 & 6.2 & 4.2 & 3.6 & 2.6 & 4.7 & 0.21 & 0.39 & 0.71 & 0.58 & - & - & - & - & - & 24.15 \\
\hline HT.06 & 29.7 & 24.9 & 7.0 & 5.8 & 4.2 & 3.0 & 2.8 & 0.79 & 0.51 & 0.66 & 0.72 & - & - & - & - & - & 20.00 \\
\hline ST.01 & 30.5 & 23.5 & 8.8 & 7.6 & 4.0 & 2.2 & 0.13 & 0.58 & 0.72 & 0.082 & - & 0.035 & 0.067 & 0.10 & 0.091 & 0.064 & 21.56 \\
\hline ST.02 & 33.1 & 20.1 & 9.1 & 7.9 & 4.3 & 2.1 & 0.074 & 0.25 & 0.77 & 0.079 & 0.93 & 0.037 & 0.068 & 0.097 & 0.094 & 0.065 & 20.78 \\
\hline ST.03 & 26.0 & 24.5 & 9.7 & 9.1 & 4.4 & 2.4 & 0.085 & 0.46 & 0.85 & 0.057 & - & 0.034 & 0.079 & 0.091 & 0.093 & 0.066 & 22.10 \\
\hline ST.04 & 30.5 & 23.2 & 7.7 & 7.6 & 4.5 & 1.7 & 0.082 & 0.37 & 0.83 & 0.053 & - & 0.027 & 0.074 & 0.085 & 1.8 & 0.062 & 21.25 \\
\hline ST.05 & 32.3 & 22.9 & 8.6 & 7.5 & 3.7 & 2.1 & 0.075 & 0.48 & 0.67 & 0.035 & - & - & - & 0.041 & - & - & 21.60 \\
\hline ST.06 & 55.7 & 3.0 & 14.5 & 11.1 & 4.9 & 3.4 & 0.054 & 0.26 & 1.0 & 0.035 & - & - & 0.0055 & 0.12 & 0.0038 & - & 5.98 \\
\hline
\end{tabular}




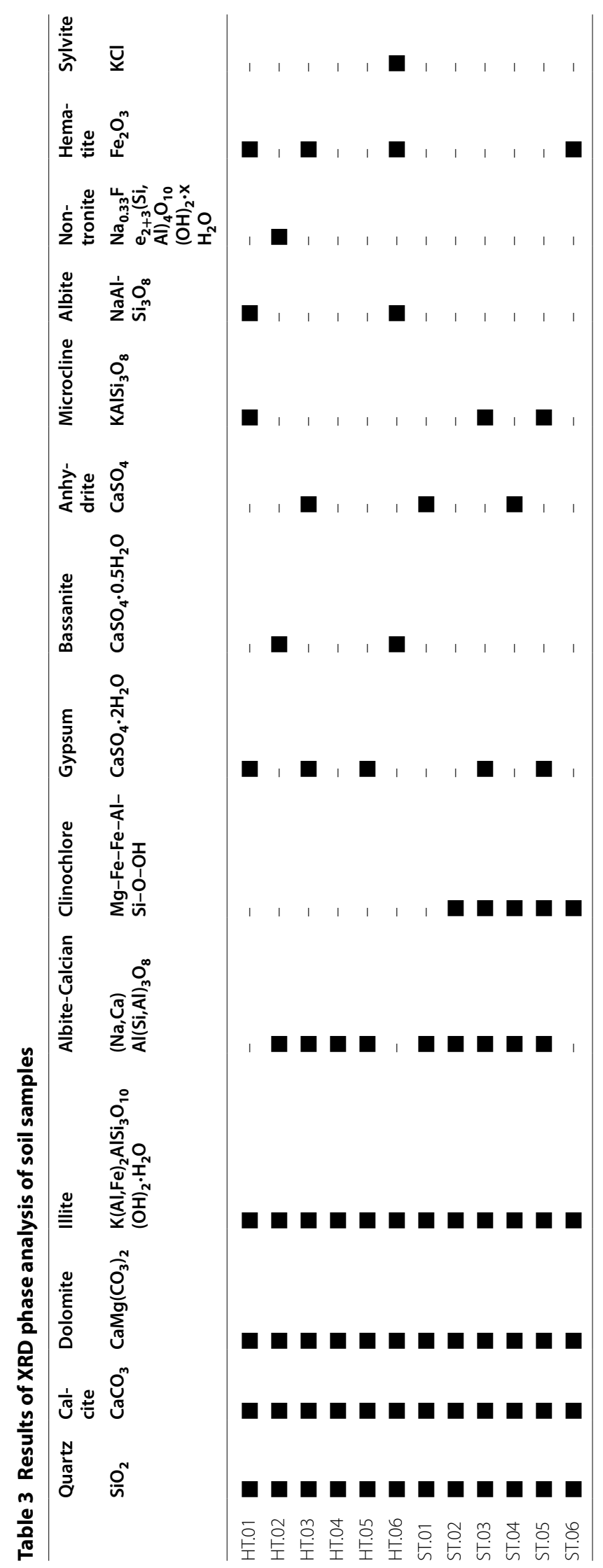


Table 4 Results of determining some factors including soil texture, electrical conductivity (EC) and pH in the studied soil samples

\begin{tabular}{|c|c|c|c|c|c|c|c|c|c|}
\hline \multirow[t]{2}{*}{ Sample } & \multicolumn{3}{|c|}{ Soil texture (\%) } & \multicolumn{2}{|c|}{ L.O.I (\%) } & \multicolumn{2}{|c|}{ Soil conductivity } & \multicolumn{2}{|l|}{$\mathrm{pH}$} \\
\hline & Sand & Silt & Clay & Water & SOM & $\mathrm{EC}(\mu \mathrm{s} / \mathrm{cm})$ & $\mathrm{T}\left({ }^{\circ} \mathrm{C}\right)$ & Soil & Distilled water \\
\hline HТ.01 & 19 & 72 & 9 & 5.27 & 2.58 & 7750 & 20.3 & 7.41 & 6.72 \\
\hline HT.02 & 14 & 67 & 19 & 2.01 & 1.71 & 3780 & 20.3 & 7.86 & \\
\hline НТ.03 & 19 & 63 & 18 & 1.69 & 3.47 & 393 & 19.2 & 7.94 & \\
\hline HT.04 & 17 & 67 & 16 & 1.70 & 1.28 & 3730 & 20.3 & 7.9 & \\
\hline HT.05 & 19 & 62 & 19 & 1.77 & 2.08 & 7440 & 19.9 & 7.88 & \\
\hline HT.06 & 20 & 65 & 15 & 2.26 & 1.14 & 3660 & 19.9 & 7.66 & \\
\hline ST.01 & 17 & 55 & 28 & 3.99 & 7.18 & 594 & 20.6 & 6.94 & 6.89 \\
\hline ST.02 & 22 & 47 & 31 & 3.38 & 2.57 & 348 & 20.0 & 7.04 & \\
\hline ST.03 & 21 & 45 & 34 & 4.02 & 6.78 & 345 & 19.3 & 7.02 & \\
\hline ST.04 & 33 & 39 & 28 & 3.52 & 5.79 & 267 & 19.2 & 7.02 & \\
\hline ST.05 & 18 & 54 & 28 & 4.14 & 8.19 & 405 & 19.3 & 6.88 & \\
\hline ST.06 & 8 & 46 & 46 & 5.17 & 6.80 & 357 & 18.7 & 6.59 & \\
\hline
\end{tabular}

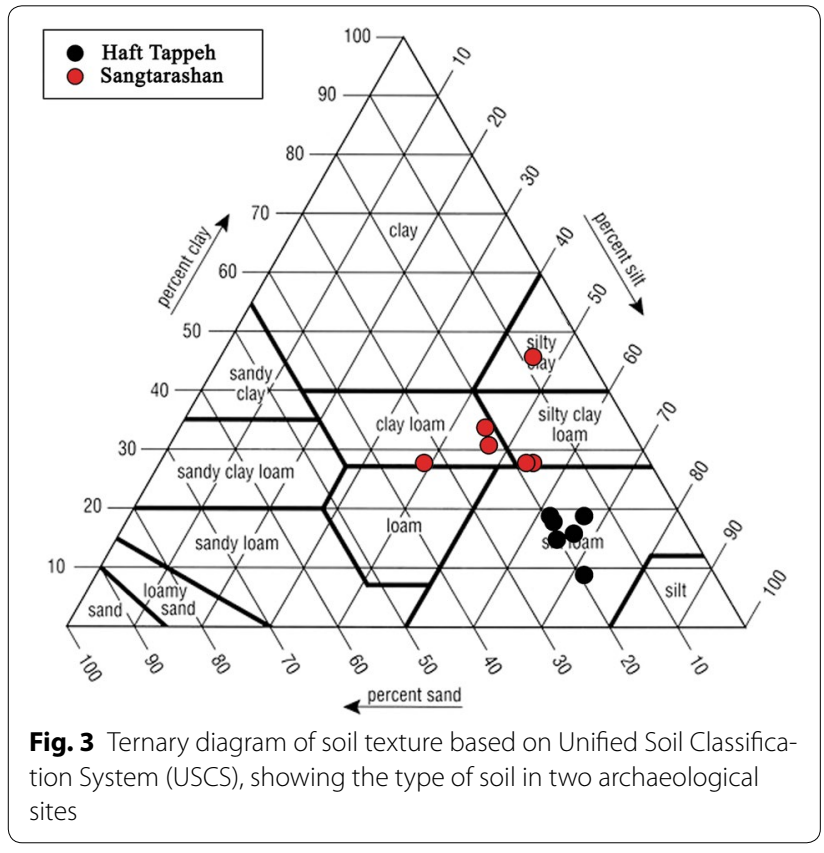

on the diagram, it is visible that the Haft Tappeh soil texture in all samples is more similar than Sangtarashan samples. The Haft Tappeh soil can be classified as silt loam, while in Sangtarashan the soil texture varies from silty clay to silty clay loam and clay loam.

Water content of the soil or water holding capacity is the resistivity of soil in losing water in the dry state and may be present in three forms: free ground water, capillary water and gravitational water [57]. Water content in Haft Tappeh soil samples is variable from 1.69 to $5.27 \%$, while it is more similar in the Sangtarashan samples. Soil organic matter (SOM) is apparently higher in
Sangtarashan samples in comparison with Haft Tappeh ones. Also, it is visible that SOM is higher in surface samples of both sites. Figure 4a presents columnar diagram showing water and SOM content in all soil samples. Based on the diagram, it is apparent that the Sangtarashan soil has high water holding capacity and also more SOM.

Electrical conductivity (EC) of soil extract shows the presence of soluble salts and salinity of soil. Electrical conductivity of soil extract was measured in the samples (Table 4). High measured EC in Haft Tappeh samples shows that the soil of this site is highly saline in comparison with Sangtarashan (despite of sample HT.03). It is visible that deep samples of Haft Tappeh have similar EC, while it has been measured more variable in the surface samples. Also the extract of black-brown (surface) samples of Sangtarashan are more conductive in comparison with the red (deep) samples (Fig. 4b).

$\mathrm{pH}$ of soil samples also was measured and the results showed that the $\mathrm{pH}$ range is slightly alkaline in Haft Tappeh samples while in Sangtarashan is more neutral (near 7) (Table 4, Fig. 4c).

Soluble anions and cations were determined by different methods explained in "Materials and Methods" section. The results are presented in Table 5. The amount of three soluble anions (chloride, sulphate and bicarbonate) in Haft Tappeh are significantly higher than the Sangtarashan soil while soluble nitrate is detected only in Sangtarashan samples. The high amount of sulphate of Haft Tappeh samples may be related to the presence of high amount of $\mathrm{SO}_{3}$ determined in XRF analysis and calcium sulphate compounds that were detected by XRD method. Soluble nitrate was only detected in Sangtarashan samples; although it has been measured in low amount, but 
a

\subsection{0}

- Water $=$ SOM

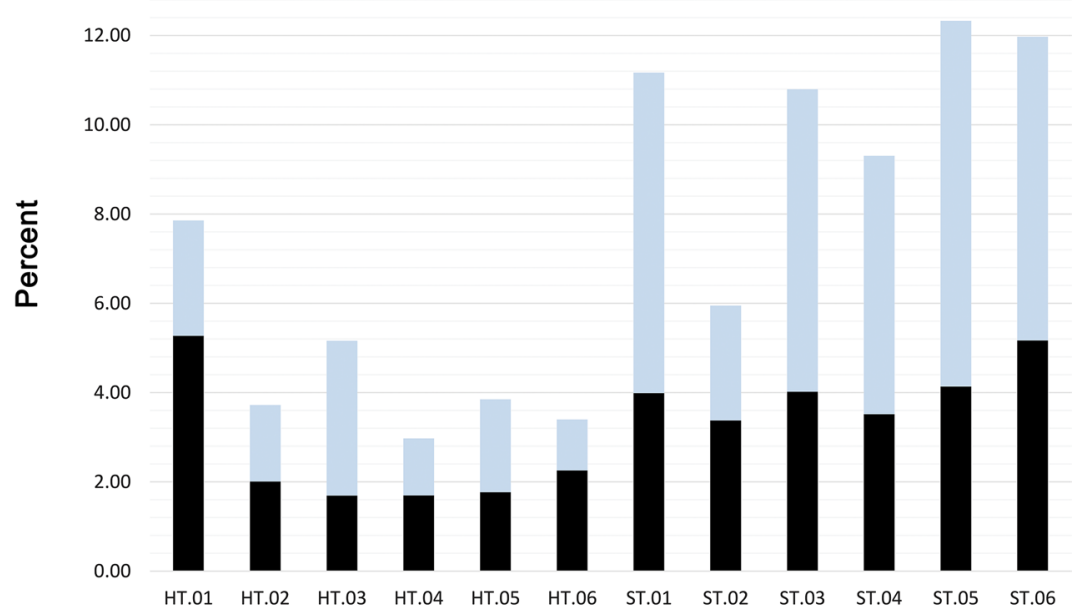

b

EC

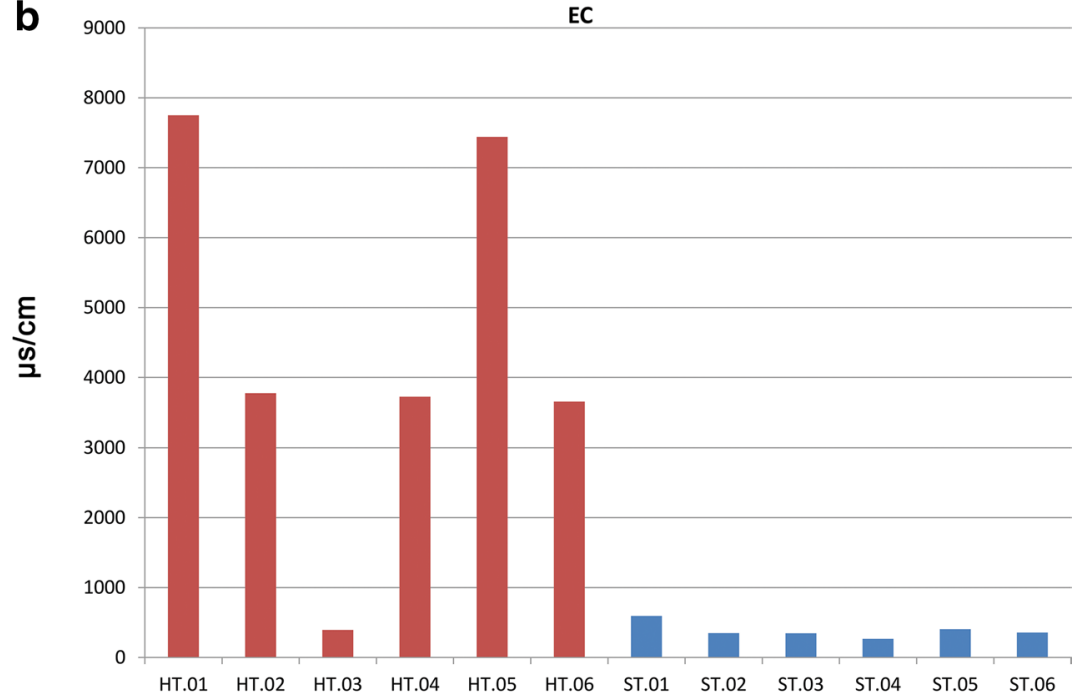

C

pH

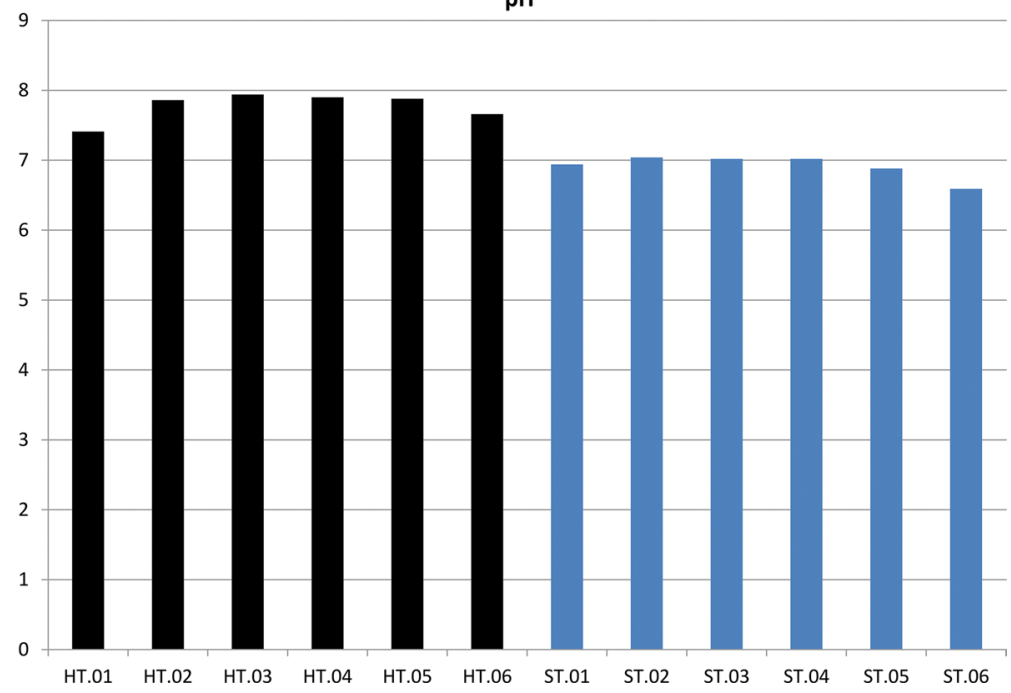

Fig. 4 Columnar diagrams of soil characteristics measured in the soil samples from archaeological sites, $\mathbf{a}$ water and SOM content, $\mathbf{b}$ electrical conductivity (EC) of soil samples, $\mathbf{c}$ pH of the soil samples 
Table 5 Results of quantitative analysis of soluble anions and cations carried out on the extract of the soil samples (mg/ kg)

\begin{tabular}{|c|c|c|c|c|c|c|c|c|}
\hline & $\mathrm{Na}^{+}$ & $\mathrm{K}^{+}$ & $\mathrm{Mg}^{2+}$ & $\mathrm{Ca}^{2+}$ & $\mathrm{Cl}^{-}$ & $\mathrm{HCO}_{3}^{-}$ & $\mathrm{SO}_{4}{ }^{2-}$ & $\mathrm{NO}_{3}{ }^{-}$ \\
\hline HТ.01 & 226.8 & 52.2 & 23.86 & 559.2 & 3404.84 & 117.12 & 16309 & n.d. \\
\hline HT.02 & 128.2 & 54.8 & 18 & 569.2 & 650.52 & 146.4 & 15350 & n.d. \\
\hline HT.03 & 108.8 & 177.6 & 7.2 & 614.2 & 377.16 & 170.8 & 16218 & n.d. \\
\hline HT.04 & 155.8 & 231.6 & 13.2 & 185.8 & 1460.2 & 131.76 & 6866 & n.d. \\
\hline HT.05 & 160.8 & 258.2 & 14 & 647.2 & 3653.98 & 122 & 16366 & n.d. \\
\hline HT.06 & 111.2 & 263.2 & 13.9 & 539.2 & 636.68 & 136.64 & 15491 & n.d. \\
\hline ST.01 & 10.3 & 14.13 & 25.16 & 80.66 & 17.32 & 5.24 & 5.2 & 96 \\
\hline ST.02 & 5.51 & 5.54 & 15.42 & 72.64 & 8.1 & 4.76 & 3.12 & 28 \\
\hline ST.03 & 7.1 & 7.39 & 15.54 & 48.74 & 16.4 & 4.68 & 3.8 & 19.2 \\
\hline ST.04 & 5.85 & 11.14 & 11.94 & 35.69 & 8.8 & 5.16 & 3 & 3.8 \\
\hline ST.05 & 10.18 & 8.37 & 15.88 & 57.44 & 16.93 & 5.24 & 4.4 & 31.2 \\
\hline ST.06 & 3.98 & 7.83 & 24.7 & 44.44 & 16.6 & 5.04 & 8.8 & 11.2 \\
\hline
\end{tabular}

it is higher in the surface sample (black-brown samples). Also the amount of soluble cations ( $\mathrm{Ca}, \mathrm{K}, \mathrm{Na}$ and $\mathrm{Mg}$ ) was determined by FAAS method showing high amount of calcium, potassium and sodium in the Haft Tappeh samples (Table 5). Also calcium concentration is detected more than other cations in Sangtarashan samples. It can be explained that high amount of soluble salts in the Haft Tappeh soil can be correlated with higher EC measured in the soil samples while it has been determined in Sangtarashan samples in very lower level.

\section{Discussion}

\section{Soil corrosivity}

The results of soil analysis in studied archaeological sites from Iran (Haft Tappeh and Sangtarashan) apparently presents that the soil environment is significantly different in two sites. In fact, these different burial environments make different effects on buried archaeological copper alloy objects during long-term burial leading to occur different corrosion mechanisms and morphologies in objects.

Phase composition of soil in Haft Tappeh shows presence of calcite and dolomite (carbonate) as main compounds and also the $\mathrm{pH}$ of soil is alkaline. Regarding that, it is possible to classify the Haft Tappeh soil as calcareous [58]. Also, calcium sulphate compounds are detected in the soil of Haft Tappeh beside chloride phase (sylvite). These phases may lead to the high salinity of Haft Tappeh soil that was also proved by EC measurement. On the other hand, the presence of high amount of soluble $\mathrm{Cl}^{-}$ and $\mathrm{SO}_{4}{ }^{2-}$ in soil states that this burial environment is a corrosive medium in which severe corrosion may occur in the long-term burial period. In fact, the presence of high amount of soluble salt results in increasing conductivity of the soil and accelerating in electrochemical reactions leading to corrosion of archaeological copper alloys [2].
As noted above, soluble sulphate is the main soluble anion was measured in the Haft Tappeh soil samples. It may be due to presence of calcium sulphate phases (and high amount of $\mathrm{SO}_{3}$ ) in the composition of soil because of gypsum used as a binder or plaster in the architecture of Haft Tappeh. Usually the presence of sulphide (metallic sulphide) and its oxidation leads to form sulphuric acid and acidifying the soil as well as decreasing pH [59], but presence of calcium sulphate phases doesn't change the $\mathrm{pH}$ of the soil [26]. In fact, slightly alkaline $\mathrm{pH}$ of Haft Tappeh soil is more due to presence of magnesium and calcium carbonates and soluble bicarbonate anion leading to $\mathrm{pH}$ about 8 . Although, calcium sulphate may also coexist with carbonates in this $\mathrm{pH}$ range $[26,60,61]$.

Silt is the main constituent of soil texture in Haft Tappeh that leads to limit absorption of water and air in the soil and also the ability of soil drying is decreased in time. In fact, higher amount of sand may cause increasing aeration and the drainage ability of the soil [22]. The water holding capacity in the Haft Tappeh may be significant due to its texture and regarding to the depth of placement metal objects as well as ground water table (low depth) on this site, it could be an important factor in corrosivity of the soil [62]. Of course, this factor should be considered beside the presence of high amount of corrosive anions in the soil.

The soil environment of Sangtarashan site is significantly different with Haft Tappeh one. Type and concentration of soluble salts are different in Sangtarashan and $\mathrm{NO}_{3}{ }^{-}$is detected as the main soluble salt in the soil. Of course, the concentration of all soluble anions is very low in comparison with Haft Tappeh soil. Presence of nitrate in the soil is in correlation with high SOM determined in the Sangtarashan soil and may be due to agricultural activities during the time. Also, EC is measured as low amount in Sangtarashan soil samples that is related to 
low amount of soluble salts in soil. $\mathrm{pH}$ of Sangtarashan soil is neutral that may be due to low concentration of soluble salts as well as the high amount of SOM [26]. The neutral $\mathrm{pH}$ can lead to decrease the rate of corrosion in the soil environment [2]. The texture of soil in Sangtarashan is variable with different percentage of sand and high percentage of clay. Clay may lead to decrease aeration of soil, but sand may lead to penetrate more water and air as well as decreasing water holding capacity and increasing rate of drainage in the soil. Regarding to the depth of placement objects, $\mathrm{pH}$, concentration of soluble salts and texture of the soil in Sangtarashan site, the soil environment could be considered as a non-corrosive or partially-corrosive medium for the archaeological copper alloy object.

Application of a numerical model is a very useful approach to estimate soil corrosivity and the effect of soil environment in archaeological metal objects based on different parameters measured in the soil $[22,63]$. There are different standard models to estimate soil corrosivity that are used in industrial studies in which the main factors are selected and considered for specific modern metals or alloys. Some important factors for archaeological copper alloys are not considered to design these standard models [64]. In fact, these models don't consider the conditions of long-term effect of soil and important factors in corrosion of copper alloy artefacts. For example, some models are considered to sulphide concentration as the important soluble anion while it has no effect on archaeological objects in the aerobic soil environment, or type and concentration of soluble salts are avoided in some corrosivity estimation models $[65,66]$.

Thus, a useful model to estimate corrosivity of soil regarding the archaeological copper alloys was considered in this research. It was designed by incorporating some different exist models to make an appropriate corrosivity estimation model useful for archaeological copper alloys [65-70]. The factors considered in this model are including:

- Soil pH (A),

- Soil organic matter (SOM) (B),

- Concentration of soluble chloride anion $(\mathrm{Cl})(\mathrm{C})$,

- Total soluble salts (TSS) measured in the soil (D),

- Water content in the soil (based on water holding capacity and the place of objects in relation with ground water table) (E),

- Soil aeration (soil texture) (F),

- Electrical conductivity (EC) of extract of the soil (G).

Table 6 shows the factors and the quantity specified for each factor (between 0 and 10). The corrosivity of soil is quantified based on the following equation:
Soil corrosivity index $(\mathrm{SCI})=\mathrm{A}+\mathrm{B}+\mathrm{C}+\mathrm{D}+\mathrm{E}+\mathrm{F}+\mathrm{G}$

Then the soil corrosivity is classified into four groups: non-corrosive (0-10), partially corrosive (11-20), corrosive (21-30) and severely corrosive (31-40). Figure 5 shows the columnar diagram of soil corrosivity index of the soil samples analysed in two archaeological sites. It is obvious that the SCI for Haft Tappeh soil samples varies from 27 to 35 and is less than 30 only in one sample. Thus, the Haft Tappeh soil could be classified as severely corrosive soil for archaeological copper alloy objects. On the other hand, SCI is calculated between 14 and 18 in Sangtarashan soil samples showing that the soil environment in this archaeological site is partially corrosive.

The Haft Tappeh archaeological site is located in the alluvial plain of Khuzestan that includes a southeastern extension of the Mesopotamian plain and a part of the Zagros Mountains to the northeast. The Zagros mountain is drained by several rivers, that have built up large alluvial fans and partially saline mud flats in this plain at the north of the Persian Gulf [71]. On the other hand, the Sangtarashan site is located in the Zagros Highlands with different geological system from Khuzestan plain and it is the most important reason for difference between soil environment in these sites [23].

\section{Soil environment and corrosion of archaeological objects}

Table 7 shows the factors used to explain Fdet in archaeological objects based on the morphology and corrosion penetration on the cross section of selected samples. Figure 6 also shows the columnar diagram indicating Fdet in objects of two sites. The diagram states that Haft Tappeh objects are corroded heavily and about $75 \%$ of studied objects are corroded completely and all metal has been transformed to corrosion products while in Sangtarashan samples, less than $50 \%$ of metal has been altered during burial time. Although in some samples of Haft Tappeh, Fdet is determined as groups G-1 to G-3 (5 samples) but it is obviously visible that the corrosion is different in two sites.

The significant finding in the analysis of soil in Haft Tappeh was high concentration of soluble sulphate ion even more than chloride. Nevertheless, the main corrosion products of Haft Tappeh objects are copper trihydroxychlorides and there is no evidence of formation of copper sulphates among corrosion layers [46]. Copper sulphates are the main corrosion products observed in the copper sculptures and monuments placed in openair urban environments [72, 73], although they may be formed in water containing soluble sulphate [74, 75]. These compounds are rare corrosion products in corroded objects buried in the soil, although there are some 
Table 6 The factors used to estimate soil corrosivity index ( $\mathrm{SCl})$ in the archaeological soil environment

\begin{tabular}{|c|c|c|c|c|}
\hline Factor & Point & Value & Measurement unit & Corrosive factor \\
\hline \multirow[t]{5}{*}{ A } & 3 & $9<$ & - & $\mathrm{pH}$ \\
\hline & 0 & $5.5-9$ & & \\
\hline & 2 & $4-5.5$ & & \\
\hline & 4 & $2-4$ & & \\
\hline & 5 & $2>$ & & \\
\hline \multirow[t]{3}{*}{ B } & 0 & No SOM & Weight percent & Soil organic matter (SOM) \\
\hline & 1 & $5>$ & & \\
\hline & 2 & $5<$ & & \\
\hline \multirow[t]{5}{*}{ C } & 1 & $10>$ & $\mathrm{mg} / \mathrm{kg}$ & Soluble chloride $\left(\mathrm{Cl}^{-}\right)$ \\
\hline & 2 & $10-50$ & & \\
\hline & 3 & 50-100 & & \\
\hline & 6 & $100-1000$ & & \\
\hline & 10 & $1000<$ & & \\
\hline \multirow[t]{7}{*}{ D } & 1 & $100>$ & $\mathrm{mg} / \mathrm{kg}$ & Total soluble salts \\
\hline & 2 & $100-200$ & & \\
\hline & 3 & $200-500$ & & \\
\hline & 5 & $500-1000$ & & \\
\hline & 7 & $1000-2500$ & & \\
\hline & 9 & $2500-5000$ & & \\
\hline & 10 & $5000<$ & & \\
\hline \multirow[t]{4}{*}{ E } & 10 & Under GWT & Ground water table (GWT) + water holding capacity (\%) & Water content \\
\hline & 8 & Around GWT & & \\
\hline & 4 & Upper than GWT-Wet soil (> 20\%) & & \\
\hline & 2 & Upper than GWT-Wet soil (<20\%) & & \\
\hline \multirow[t]{4}{*}{$\mathrm{F}$} & 6 & 60 & Percent of sand & Soil aeration \\
\hline & 4 & 40 & & \\
\hline & 3 & 20 & & \\
\hline & 0 & 0 & & \\
\hline \multirow[t]{6}{*}{ G } & 0 & $50>$ & $\mu \mathrm{s} / \mathrm{cm}$ & Soil conductivity \\
\hline & 1 & $50-100$ & & \\
\hline & 2 & $100-200$ & & \\
\hline & 4 & $200-333$ & & \\
\hline & 6 & $33-1000$ & & \\
\hline & 10 & $1000<$ & & \\
\hline \multicolumn{3}{|c|}{ Total point } & & Soil corrosivity index (SCl) \\
\hline \multicolumn{3}{|l|}{$0-10$} & & No corrosive \\
\hline \multicolumn{2}{|l|}{$11-20$} & & & Partially corrosive \\
\hline \multicolumn{2}{|l|}{$21-30$} & & & Corrosive \\
\hline \multicolumn{2}{|l|}{$31-40$} & & & Severely corrosive \\
\hline
\end{tabular}

reports about identification of copper sulphates as corrosion products in buried objects [76-79]. The basic copper sulphates are stable in acidic conditions. By changing the $\mathrm{pH}$ of environment to an alkaline condition, they will transform to more stable compounds such as tenorite $(\mathrm{CuO})$ in the open-air environments [80]. On the other hand, these products will transform to copper trihydroxychlorides (basic copper chlorides) in the presence of high concentration of soluble chloride ions [57, 81]. In fact, the main factor of formation of basic copper sulphates in open-air environments is $\mathrm{SO}_{2}[81,82]$, but because of absence of $\mathrm{SO}_{2}$ in soil environment, it is not probable to form basic copper sulphates as corrosion products in buried objects in the soil of Haft Tappeh. 


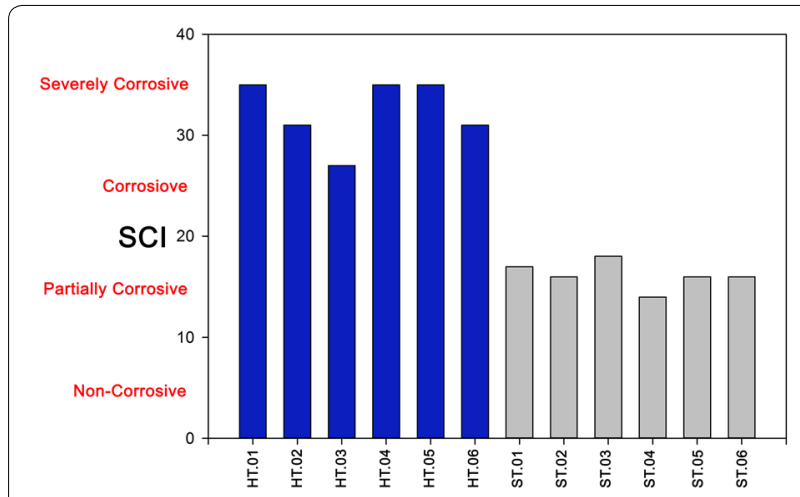

Fig. 5 Diagram showing Soil Corrosivity Index (SCl) in the soil samples analysed from two archaeological sites. The soil of Haft Tappeh is identified as severely corrosive while the Sangtarashan soil is detected as partially corrosive soil

Furthermore, the corrosion products identified in Sangtarashan objects are basic copper carbonates (malachite and azurite) [45]. As noted earlier, soluble nitrate was detected as the high concentration soluble anion in the soil samples of this site. Nevertheless, no evidence of copper nitrate compounds was observed in the analysis of corroded objects in this site. It is due to the high solubility of copper nitrate compounds that make them unstable and they are extremely rare as corrosion products in archaeological copper alloys [1]. Furthermore, sulphate compounds are found in the soil of Sangtarashan site, but no copper sulphate is detected in corrosion products of Sangtarashan bronzes. Apart from conditions of formation of copper sulphates that are explained earlier, it is also may be due to low amount of soluble sulphate ions in water of the soil. Unlike Haft Tappeh soil, sulphur is detected as minor/trace amount in the soil of Sangtarashan site (as $\mathrm{SO}_{3}$ in Table 2) and also soluble sulphate ion is determined in very low level (as $\mathrm{SO}_{4}{ }^{2-}$, Table 5). Regarding very low amount of sulphate in Sangtarashan soil, it is predictable that copper sulphate is not possible corrosion products in Sangtarashan bronzes and commonplace copper carbonates and oxides are found as corrosion products in archaeological bronzes $[1,2,45]$.

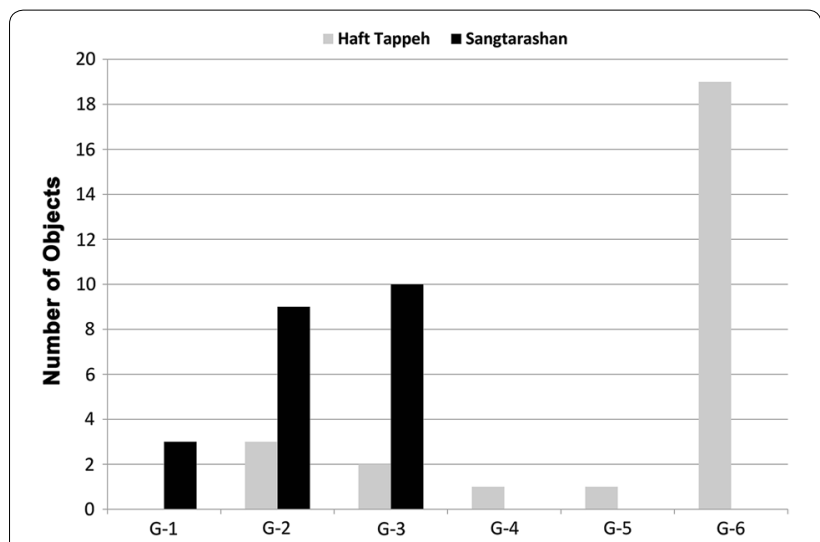

Fig. 6 Degree of deterioration (Fdet) estimated in the copper alloy objects from two archaeological sites. It is obviously visible that the corrosion rate and volume in Haft Tappeh objects is higher than the Sangtarashan bronze objects

Based on the results and their explanation, it could be obviously deduced that the main corrosive factors in the aerobic soil environments are the presence of chloride ion and water in long-term burial period. It has been noted in literature that water capacity of soil (including soil texture and soil moisture) and anions (soil composition) such as chloride are very important factors to make burial environment as corrosive media (e.g. $[1,2,19,20$, 22]). Of course, many factors are considered as factors influencing the corrosivity of soil but chloride and moisture are noted as the main factors that also influence others in the soil. As noted above, the active corrosion has been occurred in the Haft Tappeh objects due to high concentration of soluble chloride in the soil medium while there are other soluble salts in its soil. In fact, the presence of free chloride ion and water is caused to occur severely corrosion in archaeological copper alloy objects, while because of no significant amount of chloride salts (ions) in Sangtarashan soil, only internal oxidation and low rate copper dissolution were occurred in the Iron Age bronze objects in this site. Of course, it is worthy to note that other factors such as $\mathrm{pH}$ are very important, but the presence of soluble alkaline earth metals and alkali metals as well as soluble bicarbonate in soil water are led

Table 7 Characteristics used to estimate degree of deterioration (Fdet) of different groups of copper alloy objects in this study

\begin{tabular}{|c|c|c|c|}
\hline Corrosion type & Characteristics & Corrosion percentage & Group \\
\hline Almost no corrosion & Almost all of metal is retained & $<10$ & G-1 \\
\hline Minor corrosion & Thin internal corrosion layer is exist & $10-30$ & $\mathrm{G}-2$ \\
\hline Considerable corrosion & Considerable internal corrosion layer is exist & $30-50$ & G-3 \\
\hline Almost severe corrosion & Internal corrosion layer more than half of cross section & $50-70$ & G-4 \\
\hline Major corrosion & Small part of metal is retained & $70-90$ & $\mathrm{G}-5$ \\
\hline Almost no metal core & Almost all metal has been altered to corrosion products & $>90$ & G-6 \\
\hline
\end{tabular}


to make $\mathrm{pH}$ between 7 and 8 in two sites. On the other hand, other soluble anions such as sulphate and nitrate don't play an important role in the corrosion of archaeological objects. Of course, it should be considered that factors such as total soluble salts and $\mathrm{pH}$ may influence the corrosion rate in the buried objects. Furthermore, it should be noted that although the dating of the two sites (and their soil deposit) differs about 600-700 years, but the time has no role in corrosion of archaeological metal objects and is not an effective factor in degree of deterioration in archaeological metals. It is observed that the thickness of patina formed on the surface of modern buried bronzes in soil is similar to archaeological buried bronzes $[6,12,20]$. Therefore, soil conditions are the most important factor influencing long-term corrosion of archaeological bronzes.

\section{Conclusion}

Study on the corrosivity of soil environment in archaeological sites was carried out to understand important corrosion factors influencing copper alloy objects in long-term burial period. For this purpose, two archaeological sites from Iran were selected. The corrosion mechanism in copper alloy objects was studied earlier and it made opportunity to find correlation between corrosion mechanism occurred in the objects and factors influencing soil conditions for buried artefact. Based on the results, the soil environment of two studied sites is completely different based on the corrosive factors and Haft Tappeh soil could be classified as severely corrosive while Sangtarashan soil is a partially corrosive burial environment. The main corrosive factors identified in the Haft Tappeh soil are including soluble salts, especially chloride and sulphate anions and soil texture (water holding capacity) while the soil of Sangtarashan has no significant amounts of soluble anions. Regarding to the results of corrosivity of the soil and corrosion mechanism occurred in the buried copper alloy objects, it could be concluded that soluble chloride and water content are the main corrosive factors that influence long-term corrosion of archaeological copper alloy objects in burial environments. Also, application of a numerical approach to estimate soil corrosivity based on different soil factors is very useful to understand soil conditions in archaeological sites to make decisions about conservation of unearthed bronze collections in situ and in-laboratory during and after archaeological excavations.

\section{Acknowledgements}

The author is grateful to thanks Prof. Parviz Davami, Sharif University of Technology, Mehri Ghobadi, Dr. Atefeh Shekofteh, Dr. Hossein Ahmadi and Dr. Seyed Mohammadamin Emami, Art University of Isfahan, Dr. Behzad MofidiNasrabadi, Archaeological Campaign of Haft Tappeh, Ata Hasanpour and Dr. Mehrdad Malekzadeh, Archaeological Campaign of Sangtarashan and
Mozaffar Farhadpour, Choghazanbil and Haft Tappeh World Heritage Site, for their helps to undertake analyses and their comments to improve the result interpretations and the text.

\section{Competing interests}

The author declares that no competing interests.

\section{Availability of data and materials}

The dataset(s) supporting the conclusions of this article is (are) available in the article.

\section{Consent for publication \\ Not applicable.}

Ethics approval and consent to participate

Not applicable.

Funding

No funding

\section{Publisher's Note}

Springer Nature remains neutral with regard to jurisdictional claims in published maps and institutional affiliations.

Received: 23 August 2017 Accepted: 7 January 2018

Published online: 23 January 2018

\section{References}

1. Scott DA. Copper and bronze in art: corrosion, colorants and conservation. Los Angeles: Getty Conservation Institute; 2002.

2. Selwyn LS. Corrosion of metal artifacts in buried environments. In: ASM Handbook. Corrosion: environments and industries, vol. 13C. New York: ASM International; 2006. p. 306-22.

3. Chase WT. Chinese bronzes: casting, finishing, patination and corrosion. In: Scott DA, Podany J, Considine BB, editors. Ancient and historic metals: conservation and scientific research. Los Angeles: Getty Conservation Institute; 1994. p. 85-118.

4. Ingo GM, De Caro T, Riccucci C, Angelini E, Grassini S, Balbi S, Bernardini P, Salvi D, Bousselmi L, Gener M, Gouda VK. Large scale investigation of chemical composition, structure and corrosion mechanism of bronze archeological artefacts from Mediterranean basin. Appl Phys A. 2006:83:513-20.

5. Campanella L, Alessandri OC, Ferretti M, Plattner SH. The effect of tin on dezincification of archaeological copper alloys. Corros Sci. 2009;51:2183-91.

6. Robbiola L, Portier R. A global approach to the authentication of ancient bronzes based on the characterization of the alloy-patina-environment system. J Cult Heritage. 2006;7:1-12.

7. Quaranta M. On the degradation mechanisms under the influence of pedological factors through the study of archaeological bronze patina. PhD Diss., University of Bologna; 2009.

8. Papadopoulou O, Vassiliou P, Grassini S, Angelini E, Gou V. Soil-induced corrosion of ancient Roman brass - a case study. Mater Corros. 2016;67:160-9.

9. Wang $Z$, Li Y, Jiang $X$, Pan C. Research progress on ancient bronze corrosion in different environments and using different conservation techniques: a review. MRS Adv. 2017;2:2033-41.

10. Grousset $S$, Bayle M, Dauzeres A, Crusset D, Deydier V, Linard Y, Dillmann $P$, Mercier-Bion F, Neff D. Study of iron sulphides in long-term iron corrosion processes: characterisations of archaeological artefacts. Corros Sci. 2016;112:264-75.

11. von Horn C, Holstein ICC. Dents in our confidence: the interaction of damage and material properties in interpreting use-wear on copper-alloy weaponry. J Archaeol Sci. 2017:81:90-100.

12. Robbiola L, Blengino JM, Fiaud C. Morphology and mechanisms of formation of natural patinas on archaeological Cu-Sn alloys. Corros Sci. 1998;40:2083-111. 
13. Piccardo P, Mille B, Robbiola L. Tin and copper oxides in corroded archaeological bronzes. In: Dillmann P, Béranger G, Piccardo P, Matthiesen $\mathrm{H}$, editors. Corrosion of metallic heritage artefacts: investigation, conservation and prediction for long-term behaviour. European Federation of Corrosion Publication 48. Cambridge: Woodhead Publishing; 2007. p. 239-62.

14. Oudbashi O, Emami SM, Ahmadi H, Davami P. Micro-stratigraphical investigation on corrosion layers in ancient bronze artefacts by scanning electron microscopy energy dispersive spectrometry and optical microscopy. Heritage Sci. 2013;1:21.

15. Scott DA. A review of copper chlorides and related salts in bronze corrosion and as painting pigments. Stud Conserv. 2000;45:39-53.

16. Alberghina MF, Barraco R, Brai M, Schillaci T, Tranchina L. Integrated analytical methodologies for the study of corrosion processes in archaeological bronzes. Spectrochimica Acta Part B. 2011;66:129-37.

17. Soffritti C, Fabbri E, Merlin M, Garagnani GL, Monticelli C. On the degradation factors of an archaeological bronze bowl belonging to a private collection. Appl Surf Sci. 2014;313:762-70.

18. Doménech-Carbó A, Doménech-Carbó MT, Martínz-Lázaro I. Electrochemical identification of bronze corrosion products in archaeological artefacts - a case study. Microchimica Acta. 2008;162:351-9.

19. Angelini E, Rosalbino F, Grassini S, Ingo GM, De Caro T. Simulation of corrosion processes of buried archaeological bronze artefacts. In: Dillmann $\mathrm{P}$, Béranger G, Piccardo P, Matthiesen $\mathrm{H}$, editors. Corrosion of metallic heritage artefacts: investigation, conservation and prediction for long-term behaviour. European Federation of Corrosion Publication 48. Cambridge: Woodhead Publishing; 2007. p. 203-18.

20. Nord AG, Mattsson E, Tronner K. Factors influencing the long-term corrosion of bronze artefacts in soil. Protect Met. 2005;41:309-16.

21. Nord AG, Tronner K, Mattsson E, Borg GC, Ullén I. Environmental threats to buried archaeological remains. Ambio. 2005;34:256-62.

22. Gerwin W, Baumhauer R. Effect of soil parameters on the corrosion of archaeological metal finds. Geoderma. 2000;96:63-80.

23. Oudbashi $O$. Evaluation of corrosion morphology and conservation conditions in excavated bronze collections based on metal-environmentcorrosion system. PhD Thesis. Art University of Isfahan, Unpublished (in Farsi); 2013.

24. Mofidi-Nasrabadi B. Vorbericht der archäologischen Ausgrabungen der Kampagnen 2012-2013 in Haft Tappeh (Iran). Elamica. 2014;4:67-167.

25. Theocharopoulos SP, Mitsios IK, Arvanitoyannis I. Traceabilty of environmental soil measurements. Trends Anal Chem. 2004;23:237-51.

26. Pansu M, Gautheyrou J. Handbook of soil analysis: mineralogical, organic and inorganic methods. Berlin: Springer; 2006.

27. Gunicheva T. Application of nondestructive X-ray fluorescence method (XRF) in soils, friable and marine sediments and ecological materials. In: Panagiotaras D, editor. Geochemistry_earth's system processes. Rijeka: InTech; 2012. p. 372-88.

28. Goldberg P, Macphail RI. Practical and theoretical geoarchaeology. Oxford: Blackwell Publishing; 2006.

29. Shrivastava VS. X-ray diffraction and mineralogical study of soil: a review. J Appl Chem Res. 2009;9:41-51.

30. Mitchell JK, Soga K. Fundamentals of soil behavior. 3rd ed. New York: Wiley; 2005.

31. ASTM D422-63. Standard test method for particle-size analysis of soils West Conshohocken: ASTM International; 2002. https://doi.org/10.1520/ d0422-63r02.

32. ASTM D2974-00. Standard test methods for moisture, ash, and organic matter of peat and other organic soils. West Conshohocken: ASTM International; 2000. https://doi.org/10.1520/d2974-00.

33. Howard PJA, Howard DM. Use of organic carbon and loss-on-ignition to estimate soil organic matter in different soil types and horizons. Biol Fertil Soils. 1990;9:306-10.

34. Storer DA. A simple high sample volume ashing procedure for determining soil organic matter. Commun Soil Sci Plant Anal. 1984;15:759-72.

35. Schulte EE., Hoskins B. Recommended soil organic matter tests. In: Recommended soil testing procedures for the Northeastern United States. Northeastern Regional Publication No. 493, 3rd ed. 2011.

36. Konare H, Yost RS, Doumbia M, McCarty GW, Jarju A, Kablan R. Loss on ignition: measuring soil organic carbon in soils of the Sahel, West Africa. Afr J Agri Res. 2010;5:3088-95.
37. ASTM D4972-01. Standard test method for pH of soils. West Conshohocken: ASTM International; 2007. https://doi.org/10.1520/d4972-01 r07.

38. Shirokova Y, Forkutsa I, Sharafutdinova N. Use of electrical conductivity instead of soluble salts for soil salinity monitoring in Central Asia. Irrig Drainage Syst. 2000;14:199-205.

39. Miller JJ, Curtin D. Electrical conductivity and soluble ions. In: Carter MR, Gregorich EG, editors. Soil sampling and methods of analysis. 2nd ed. Abingdon: Taylor \& Francis; 2008.

40. Sparks DL. Environmental soil chemistry. 2nd ed. London: Academic Press; 2003

41. Odegaard N, Carroll S, Zimmet WS. Material characterization tests for objects of art and archaeology. 2nd ed. London: Archetype Publications; 2005.

42. ASTM D1411-09. Standard test methods for water-soluble chlorides present as admixtures in graded aggregate road mixes. West Conshohocken: ASTM International; 2009. https://doi.org/10.1520/d1411-09.

43. ASTM D1067-06. Standard test methods for acidity or alkalinity of water. West Conshohocken: ASTM International; 2006. https://doi.org/10.1520/ d1067-06.

44. Marko-Varga G, Csiky I, Joensson JA. On-chromatographic determination of nitrate and sulfate in natural waters containing humic substances. Anal Chem. 1984;56:2066-9.

45. Oudbashi O, Hasanpour A, Davami P. Investigation on corrosion stratigraphy and morphology in some iron age bronze alloys vessels by $\mathrm{OM}, \mathrm{XRD}$ and SEM-EDS methods. Appl Phys A. 2016;122:262.

46. Oudbashi O. Multianalytical study of corrosion layers in some archaeological copper alloy artefacts. Surf Interface Anal. 2015;47:1133-47.

47. Scott DA. Bronze disease: a review of some chemical problems and the role of relative humidity. JAIC. 1990;29:193-206.

48. Alvarez-Mon J. Aspects of elamite wall painting: new evidence from Kabnak (Haft Tappeh). Iranica Antiqua. 2005;40:149-64.

49. Mofidi Nasrabadi B. Arbeitszimmer eines Schreibers aus der mittelelamischen Zeit. In: Wilhelm G, editors. Organisation, representation, and symbols of power in the ancient near east. Proceedings of the 54th rencontre Assyriologique Internationale at Würzburg. 20-25 July 2008. Indiana: Winona Lake; 2012. p 747-56.

50. Mofidi Nasrabadi B. Elam: Archaeology and history. In: Stöllner T, Slotta R, Vatandoust A, editors. Persiens Antike Pracht, Bergbau Handwerk Archäologie, exhibition catalogue. Bochum: Deutsches Bergbau-Museum; 2004. p. 294-309.

51. Oudbashi O, Emami SM, Malekzadeh M, Hassanpour A, Davami P. Archaeometallurgical studies on the bronze vessels from "Sangtarashan", Luristan, W-Iran. Iranica Antiqua. 2013;48:147-74.

52. Color Munsell. Munsell soil color charts. Grand Rapids: GretagMacbeth LLC; 2000.

53. Johnston-Feller R. Color science in the examination of museum objects. Nondestructive procedures. Los Angeles: Getty Conservation Institute; 2001.

54. Gerharz RR, Lantermann R, Spennemann DR. Munsell color charts: a necessity for archaeologists? Aust Hist Archaeol. 1988;6:88-95.

55. ASTM D2487-11. Standard practice for classification of soils for engineering purposes (Unified Soil Classification System). West Conshohocken: ASTM International; 2011.

56. Soil Survey Division Staff. Soil survey manual. Soil conservation service. US Department of Agriculture Handbook 18; 1993.

57. Veleva L. Soils. In: Baboian R, editor. Corrosion tests and standards: application and interpretation. 2nd ed. West Conshohocken: ASTM International; 2005.

58. Chesworth W, Arbestain MC, Macías F. Calcareous soils. In: Chesworth W, editor. Encyclopedia of soil science, part of the series encyclopedia of earth sciences series. Netherlands: Springer; 2008. p. 77-9.

59. Vuai SA, Nakamura K, Tokuyama A. Geochemical characteristics of runoff from acid sulfate soils in the northern area of Okinawa Island, Japan. Geochem J. 2003;37:579-92.

60. Robarge WP. Acidity. In: Chesworth W, editor. Encyclopedia of soil science, part of the series encyclopedia of earth sciences series. Netherlands: Springer; 2008. p. 10-20.

61. Barber SA. Soil nutrient bioavailability: a mechanistic approach. 2nd ed. New York: Wiley; 1995. 
62. Yahaya N, Lim KS, Noor NM, Othman SR, Abdullah A. Effects of clay and moisture content on soil-corrosion dynamic. Malaysia J Civil Eng. 2011;23:24-32.

63. Wagner D, Dakoronia F, Ferguson C, Fischer WR, Hills C, Kars H, Meijers R. "Soil Archive" classification in terms of impacts of conservability of archaeological heritage. In: MacLeod ID, Pennec SL, Robbiola L, editors. Metal 95, Proceedings of the international conference on metals conservation. Semur en Auxois, 25-28 Sept. 1995. London: James \& James. 1997. p 21-6.

64. AWWA Staff. Ductile-Iron Pipe and Fittings. 3rd ed. M41 AWWA Manual. American Water Works Association; 2011.

65. Corrosion Survey and Standardization of Korea. n.d. Soil corrosivity analysis. http://www.corrosionsurvey.co.kr/viewer/pdf/n_02.pdf. Accessed 20 Feb 2012.

66. Samtani NC, Nowatzki EA, Hollow bar soil nails-review of corrosion factors and mitigation practice. Publication No. FHWA-CFL/TD-10-002, Central Federal Lands Highway Division; 2010. http://www.cflhd.gov/programs/techDevelopment/geotech/corrosion/01_HBSN_Corrosion_Factors_Mitigation.pdf. Accessed 15 Dec 2012.

67. Fernandes R. Study on roman and merovingian copper alloyed artefacts. In: Soil corrosion processes and recycling practices. M.Sc. Thesis. (O-variant). Vrije Universiteit Amsterdam; 2009.

68. AlHazzaa MI. A comparative study of soil corrosivity of the university compass. Final Research Report No.45/426. Research Center of College of Engineering. King Saud University; 2007.

69. Durr CL, Beavers JA. Techniques for assessment of soil corrosivity. In: Corrosion 98, 22-27 March 1998. San Diego: NACE International; 1998.

70. Liu Z, Sadiq R, Rajani B, Najjaran H. Exploring the relationship between soil properties and deterioration of metallic pipes using predictive data mining methods. J Comput Civil Eng. 2010;24:289-301.

71. Bogemans F, Janssens R, Baeteman C. Depositional evolution of the Lower Khuzestan plain (SW Iran) since the end of the Late Pleistocene. Quatern Sci Rev. 2017;171:154-65.

72. Martens WN, Frost RL, Kloprogge JT, Williams PA. Raman spectroscopic study of the basic copper sulphates-implications for copper corrosion and 'bronze disease'. J Raman Spectrosc. 2003;34:145-51.
73. Fitzgerald KP, Nairn J, Skennerton G, Atrens A. Atmospheric corrosion of copper and the colour, structure and composition of natural patinas on copper. Corros Sci. 2006;48:2480-509.

74. Krapchev TA. Literary survey on corrosion and corrosion products of copper and bronze observed in ancient artifacts. B.Sc. Thesis. Massachuset Institute of Technology; 1976.

75. Lins A, Power T. The corrosion of bronze monuments in polluted urban sites: a report on the stability of copper mineral species at different $\mathrm{pH}$ levels. In: Scott DA, Podany J, Considine BB, editors. Ancient and historic metals: conservation and scientific research. Los Angeles: Getty Conservation Institute; 1994. p. 119-51.

76. Balasubramaniam R, Mungole MN, Prabhakar VN. Studies on ancient Indian OCP period copper. Indian J Hist Sci. 2002;37:1-15.

77. Schweizer F. Bronze objects from lake sites: from patina to "Biography". In: Scott DA, Podany J, Considine BB, editors. Ancient and historic metals: conservation and scientific research. Los Angeles: Getty Conservation Institute; 1994. p. 33-50.

78. Mattsson E, Nord AG, Tronner K, Fjaestad M, Lagerlöf A, Ullén I, Borg GC. Deterioration of archaeological material in soil, Results on bronze artefacts. Konserveringstekniska Studier RIK. Riksantikvariëambetet och Statens Historiska Museer 10. Stockholm: Riksantikvarieämbetet Förlag; 1996.

79. Tronner K, Nord AG, Borg GC. Corrosion of archaeological bronze artefacts in acidic soil. Water Air Soil Pollut. 1995;85:2725-30.

80. Marani D, Patterson JW, Anderson PR. Alkaline precipitation and aging of Cu(II) in the presence of sulfate. Water Res. 1995;29:1317-26.

81. Strandberg H. Reactions of copper patina compounds-II. Influence of sodium chloride in the presence of some air pollutants. Atmos Environ. 1998;32:3521-6.

82. Strandberg H. Reactions of copper patina compounds-I. Influence of some air pollutants. Atmos Environ. 1998;32:3511-20.

\section{Submit your manuscript to a SpringerOpen ${ }^{\circ}$ journal and benefit from:}

- Convenient online submission

- Rigorous peer review

- Open access: articles freely available online

- High visibility within the field

- Retaining the copyright to your article

Submit your next manuscript at $\boldsymbol{\nabla}$ springeropen.com 